\title{
Effects of Changes in Precipitation and Temperature on Select Agrophage Risk in Poland, 1965-2009
}

\author{
Felicyta Walczak ${ }^{1}$, Anna Tratwal ${ }^{1 *}$, Jan Bocianowski ${ }^{2}$ \\ 'Institute of Plant Protection - National Research Institute, \\ Węgorka 20, 60-318 Poznań, Poland \\ ${ }^{2}$ Department of Mathematical and Statistical Methods, Poznań University of Life Sciences, \\ Wojska Polskiego 28, 60-637 Poznań, Poland
}

Received: 7 April 2014

Accepted: 8 July 2014

\begin{abstract}
Agriculture is a branch of the economy seriously influenced by climate change, particularly in terms of the incidence and damage potential of crop agrophages. Precipitation and air temperature recorded over the last 44 years in five select locations in Poland were analyzed in order to determine whether and to what extent climate change had actually occurred. Monthly precipitation totals and mean air temperatures were analyzed in terms of seasons, taking into consideration the course of vegetation of both spring and winter crops and development of pests. The aim of the study was to determine how precipitation and air temperature change and to present a preliminary evaluation of their effects on the level of damages of economically important agrophages, for several decades covered by nationwide monitoring in Poland. On the basis of results of descriptive statistics it was found that the highest value of the coefficient of variation for precipitation over a period of 44 years was recorded in autumn, while for air temperature it was in winter. After the 44-year period had been divided into four 11-year periods, the last 11 years (1999-2009) showed that the mean value of air temperature in relation to the years $1988-98\left(1.5^{\circ} \mathrm{C}\right)$ decreased only in winter, although the mean value was still above zero $\left(0.9^{\circ} \mathrm{C}\right)$. In the other seasons in the years 1999-2009 it was the highest. In turn, mean precipitation levels for the last 11 years were highest only in winter. An increase in precipitation in the winter months could have been one of the factors contributing to a reduction of populations of wintering pest stages. Stable precipitation patterns and increasing temperatures in spring could have contributed to the development of e.g. the European corn borer, while it may have limited the intensity of fungal crop diseases.
\end{abstract}

Keywords: climate changes, crop agrophages

\section{Introduction}

Agriculture is a branch of the economy considerably affected by climate change [1-3]. It is already clearly manifested in many locations worldwide. Additionally, in countries of Central and Eastern Europe climate change has

*e-mail: A.Tratwal@iorpib.poznan.pl coincided with revolutionary social and political transformations, which have had a great impact on their economies. This definitely pertains also to Poland. Profound changes have been found in practically all aspects of the economy, including agriculture [4-5]. It is difficult to distinguish a natural developmental progress, advances resulting from Poland's accession to the EU, and finally changes resulting from the evolution of the climate. In agriculture the intensi- 
fication of agrophage damage seems to be such an area in which this distinction is possible [6]. Unfortunately, there are very few studies discussing the above-mentioned problem. They are generally papers presenting scenarios concerning the occurrence of specific agrophage species in cases of an increase in air temperature and either lower or higher humidity [7-8].

In view of the fact that the progressing climate change may influence the economic importance of agrophages of agricultural crops, analyses were conducted to investigate the course of mean monthly air temperatures and precipitation totals in Poland recorded over a period of 44 years at five select locations, i.e Koszalin, Poznań, Warszawa, Wrocław, and Rzeszów, representing different local climates of Poland. According to the newest IPCC report [9], the 11-years solar cycle contributes on average 10-15\% only to the temperature signal, on the other hand temperatures have high influence on pest development and its occurrence intensity. Taking into consideration the course of vegetation in both spring and winter crops and the development of pests, meteorological data coming from standard weather stations of the Institute of Meteorology and Water Management [10] were divided in terms of seasons of the year.

The aim of the study was to analyze select meteorological parameters (air temperature and precipitation) associated most closely with the course of crop phenology, and to conduct a preliminary analysis of their effect on the level of damage potential of select economically important pests covered by nationwide monitoring of their harmfulness in Poland.

\section{Methods}

\section{Analysis of Meteorological Data}

An analysis was conducted for precipitation and air temperatures for select sites, i.e. Koszalin, Poznań, Warszawa, Wrocław, and Rzeszów (Fig. 1).

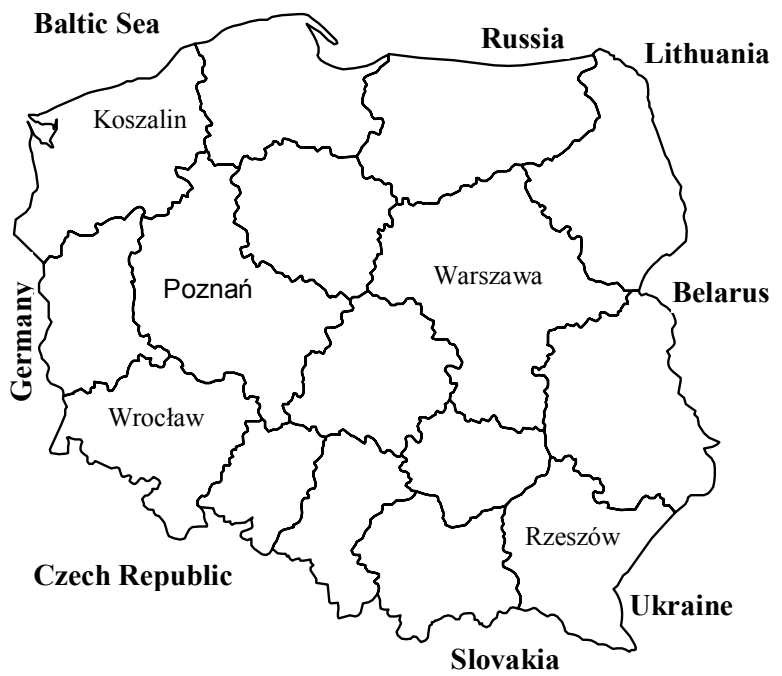

Fig. 1. An orientation map of locations for selected cities in Poland.
Available data presented monthly precipitation totals and mean monthly air temperatures (statistical units). Taking into consideration the vegetation season for winter crops, autumn periods in the years 1965-2008 were analyzed first, followed by winter, spring, and summer seasons this time in 1966-2009 (a continuation of winter crop vegetation). When dividing the year into seasons of the year the following principle was adopted to include 3 months to each season: autumn comprised October, November, and December; winter included January, February and March; spring was April, May, and June; while summer was July, August, and September.

Measures of data scattering were investigated, i.e. average levels of precipitation totals and mean air temperatures, as well as the ranges of variation (minimum and maximum), the coefficient of variation [11], standard deviation for 44 years of each season, treating all the selected sites jointly (mean monthly precipitation totals for 44 years $\times 5$ cities separately for each season of the year). The aim of this analysis was to confirm in which season of the year the analyzed meteorological data exhibited the greatest variation over the period of 44 years.

In order to verify whether over the 44 analyzed years changes occurred for the select meteorological parameters and how trends for these changes affect the intensification of damages of the select agrophages it was decided to divide the 44 years into four shorter periods. In view of the extensive discussion in literature on the effect of the 11-year solar cycle on temperature and other weather parameters on Earth [1218], such a period was considered in further analyses.

The above-mentioned measures of scatter were investigated for the analyzed meteorological data, treating the selected cities jointly and separately for each of the four cycles (I, II, III, IV) within each season of the year (11 years $\times 5$ cities for each of the 4 cycles, in each of the four seasons).

In Poland every year the Plant Protection and Seed Health Inspection Service in collaboration with the Institute of Plant Protection - National Research Institute provide detailed field observations in order to get the information about phytosanitary state of agricultural plants. Damages caused by pests are evaluated on the base of field observations at the end of the vegetation season.

Intensity of pest damages are presented in the form of national means of the percentages of damaged plants, culms, ears, siliques, and flower buds, depending on the specific character of damage potential for a given agrophage, separately for each of the four solar cycles. Agrophages of high economic importance, monitored in Poland for 3 to 4 11-year periods, were selected for analyses. The mean values for the intensity of pest damage potential on the national scale for each of the 4 solar cycles were ascribed to mean precipitation levels or mean air temperatures calculated for the five selected cities, but separately for each of the four solar cycles and a specific seasons. In these comparisons such a season was considered, which in view of biology of a given agrophage influences its population size or the intensity of disease symptoms, and thus the level of damage potential. 
Table 1. Measurements of scatter for precipitation totals and mean air temperatures for five cities in Poland treated jointly from a 44year period, presented separately for each season.

\begin{tabular}{|c|c|c|c|c|c|}
\hline Season & $\begin{array}{l}\text { Precipitation total in } \mathrm{mm} / \\
\text { mean air temperature in }{ }^{\circ} \mathrm{C}\end{array}$ & $\begin{array}{l}\text { Minimum } \\
\left(\mathrm{mm} /{ }^{\circ} \mathrm{C}\right)\end{array}$ & $\underset{\left(\mathrm{mm} /{ }^{\circ} \mathrm{C}\right)}{\operatorname{Maximum}}$ & $\begin{array}{c}\text { Coefficient } \\
\text { of variation (\%) }\end{array}$ & $\begin{array}{l}\text { Standard deviation } \\
\left(\mathrm{mm} /{ }^{\circ} \mathrm{C}\right)\end{array}$ \\
\hline \multicolumn{6}{|c|}{ Precipitation in $1965-2008$} \\
\hline Autumn & 132.7 & 35.0 & 384.0 & 43.8 & 58.1 \\
\hline \multicolumn{6}{|c|}{ Precipitation in 1966-2009 } \\
\hline Winter & 97.7 & 31.0 & 229.7 & 38.6 & 37.7 \\
\hline Spring & 168.9 & 50.0 & 417.0 & 33.3 & 56.3 \\
\hline Summer & 207.6 & 56.0 & 491.0 & 36.4 & 75.6 \\
\hline \multicolumn{6}{|c|}{ Temperature in $1965-2008$} \\
\hline Autumn & 4.1 & 0.8 & 8.3 & 29.0 & 1.2 \\
\hline \multicolumn{6}{|c|}{ Temperature in $1966-2009$} \\
\hline Winter & 0.3 & -5.7 & 5.3 & 708.5 & 2.3 \\
\hline Spring & 12.4 & 7.3 & 15.2 & 10.7 & 1.3 \\
\hline Summer & 16.4 & 13.8 & 19.6 & 7.1 & 1.2 \\
\hline
\end{tabular}

Italic text means the highest values of coefficient of variation for each season.

Table 2. Measurements of scatter for values of precipitation totals for five selected cities treated jointly, presented separately for each of the four solar cycles and each season.

\begin{tabular}{|c|c|c|c|c|c|}
\hline $\begin{array}{l}\text { Solar } \\
\text { cycles }\end{array}$ & $\begin{array}{l}\text { Precipitation totals } \\
\text { (mm) }\end{array}$ & $\begin{array}{l}\text { Minimum } \\
(\mathrm{mm})\end{array}$ & $\begin{array}{l}\text { Maximum } \\
\quad(\mathrm{mm})\end{array}$ & $\begin{array}{c}\text { Coefficient of variation } \\
(\%)\end{array}$ & $\begin{array}{l}\text { Standard deviation } \\
(\mathrm{mm})\end{array}$ \\
\hline \multicolumn{6}{|c|}{ Autumn - in 1965-75 (I), 1976-86 (II), 1987-97 (III), 1998-2008 (IV) } \\
\hline I & 145.6 & 35.0 & 384.0 & 52.1 & 75.9 \\
\hline II & 139.5 & 60.3 & 319.0 & 42.4 & 59.2 \\
\hline III & 119.2 & 53.2 & 215.0 & 35.9 & 42.8 \\
\hline IV & 126.3 & 64.0 & 249.2 & 35.3 & 44.6 \\
\hline \multicolumn{6}{|c|}{ Winter - in 1966-76 (I), 1977-87 (II), 1988-98 (III), 1999-2009 (IV) } \\
\hline I \% & 90.8 & 34.0 & 169.0 & 32.0 & 29.1 \\
\hline II & 89.0 & 39.2 & 187.4 & 37.3 & 33.2 \\
\hline III & 94.8 & 31.0 & 209.0 & 45.0 & 42.6 \\
\hline IV & 116.4 & 47.1 & 229.7 & 32.7 & 38.1 \\
\hline \multicolumn{6}{|c|}{ Spring - in 1966-76 (I), 1977-87 (II), 1988-98 (III), 1999-2009 (IV) } \\
\hline I & 178.7 & 52.2 & 417.0 & 33.8 & 60.4 \\
\hline II & 170.2 & 59.0 & 285.4 & 29.2 & 49.6 \\
\hline III & 162.3 & 50.0 & 342.0 & 34.7 & 56.2 \\
\hline IV & 164.6 & 65.6 & 293.0 & 34.6 & 57.0 \\
\hline \multicolumn{6}{|c|}{ Summer - in 1966-76 (I), 1977-87 (II), 1988-98 (III), 1999-2009 (IV) } \\
\hline I & 194.8 & 77.5 & 345.0 & 33.8 & 65.9 \\
\hline II & 217.2 & 56.0 & 491.0 & 42.0 & 91.2 \\
\hline III & 206.4 & 84.0 & 412.0 & 35.3 & 72.7 \\
\hline IV & 211.9 & 73.0 & 364.3 & 32.1 & 67.9 \\
\hline
\end{tabular}

Bold text means the minimal and maximal values for each season. Italic text means the highest values of coefficient of variation for each season. 
Table 3. Measurements of scatter for mean values of air temperature for the five selected cities treated jointly, presented jointly for each solar cycle and each season.

\begin{tabular}{|c|c|c|c|c|c|}
\hline $\begin{array}{l}\text { Solar } \\
\text { cycles }\end{array}$ & $\begin{array}{l}\text { Temperature } \\
(\mathrm{mm})\end{array}$ & $\begin{array}{l}\text { Min. } \\
(\mathrm{mm})\end{array}$ & $\begin{array}{l}\text { Max. } \\
(\mathrm{mm})\end{array}$ & $\begin{array}{c}\text { Coefficient of variation } \\
(\%)\end{array}$ & $\begin{array}{c}\text { Standard deviation } \\
(\mathrm{mm})\end{array}$ \\
\hline \multicolumn{6}{|c|}{ Autumn - in 1965-75 (I), 1976-1986 (II), 1987-97 (III), 1998-2008 (IV) } \\
\hline I & 3.9 & 1.7 & 5.6 & 23.1 & 0.9 \\
\hline II & 4.2 & 2.9 & 6.0 & 19.5 & 0.8 \\
\hline III & 3.9 & 1.5 & 5.5 & 18.8 & 0.7 \\
\hline IV & 4.6 & 0.8 & 8.3 & 42.6 & 2.0 \\
\hline \multicolumn{6}{|c|}{ Winter - in 1966-76 (I), 1977-87 (II), 1988-98 (III), 1999-2009 (IV) } \\
\hline I & -0.1 & -4.2 & 3.4 & -2055.2 & 1.9 \\
\hline II & -1.0 & -5.7 & 2.5 & -217.9 & 2.2 \\
\hline III & 1.5 & -4.6 & 5.3 & 145.6 & 2.1 \\
\hline IV & 0.9 & -4.0 & 4.7 & 216.6 & 2.0 \\
\hline \multicolumn{6}{|c|}{ Spring - in 1966-76 (I), 1977-87 (II), 1988-98 (III), 1999-2009 (IV) } \\
\hline I & 11.8 & 7.3 & 13.7 & 10.6 & 1.3 \\
\hline II & 11.9 & 9.4 & 14.1 & 9.9 & 1.2 \\
\hline III & 12.5 & 9.0 & 14.3 & 8.9 & 1.1 \\
\hline IV & 13.5 & 11.1 & 15.2 & 7.8 & 1.0 \\
\hline \multicolumn{6}{|c|}{ Summer - in 1966-76 (I), 1977-87 (II), 1988-98 (III), 1999-2009 (IV) } \\
\hline I & 16.2 & 14.6 & 18.7 & 5.2 & 0.8 \\
\hline II & 15.7 & 13.9 & 18.2 & 6.3 & 1.0 \\
\hline III & 16.5 & 13.8 & 18.7 & 7.3 & 1.2 \\
\hline IV & 17.4 & 14.9 & 19.6 & 5.2 & 0.9 \\
\hline
\end{tabular}

Bold text means the minimal and maximal values for each season. Italic text means the highest values of coefficient of variation for each season.

The obtained results were statistically evaluated. A twoway analysis of variance (ANOVA) was performed to verify the hypothesis of lack of effects of locations and cycles and hypothesis about a lack of locations $\times$ cycles interaction on the variability of precipitation and air temperatures. Data analysis was performed using the statistical package GenStat, $15^{\text {th }}$ edition.

\section{Results}

Analysis of variance indicated that the main effects of locations (Koszalin, Poznań, Warszawa, Wrocław, and Rzeszów) and cycles (I, II, III, and IV) as well as locations $\times$ cycles interaction were significant for precipitation and air temperatures $(\mathrm{P}<0.001)$. Results of calculations concerning descriptive statistics for precipitation totals and mean temperatures in each of the four seasons over a period of 44 years, i.e. autumn in the period of 1965-2008 and analogously winter, spring, and summer in the period of 1966-2009 for the five selected cities treated jointly, are presented in Table 1.

Statistical analyses of the investigated meteorological data focused mainly on comparisons of values of the coefficients of variations and mean values (Table 1).
When evaluating the recorded values separately for each season it was found that in the case of precipitation the greatest value of the coefficient of variation was recorded in autumn [6], while in the case of air temperature it was in winter, and to a considerable degree also in autumn in comparison to the value of the coefficient recorded for spring and summer (Table 1).

There is a significant correlation between solar cycle precipitation and air temperature $(\mathrm{P}<0.001)$, but this alone does not proove a causal relationship. Next we investigated in which of the four solar cycles in each of the seasons was the value of the coefficient of variation for precipitation and air temperature highest. Moreover, mean values of precipitation and air temperature were compared in order to verify whether changes had occurred and whether they concerned the last analyzed cycle (i.e. cycle IV) (Tables 2 and 3).

The highest coefficient of variation for precipitation was recorded for autumn in the $1^{\text {st }}$ solar cycle, amounting to $52.1 \%(1966-76)$, while it was lowest for spring in the $2^{\text {nd }}$ cycle, i.e. $29.2 \%$ (1977-87).

In autumn the highest values both for precipitation totals and the coefficient of variation were calculated for the $1^{\text {st }}$ cycle (1965-75), while the lowest precipitation total was found for the $3^{\text {rd }}$ cycle (1987-97). In the case of win- 
Table 4. National means for damages caused by incidence of winter wheat diseases, pests of winter rape, potato, and corn in 19662009 being averages for each of the four solar cycles.

\begin{tabular}{|c|c|c|c|c|}
\hline \multirow{2}{*}{ Pests/Damages } & \multicolumn{4}{|c|}{ Solar cycles } \\
\hline & I & II & III & IV \\
\hline European corn borer (Ostrinia nubilalis) - \% damaged corn plants & 2.9 & 3.1 & 3.8 & 6.4 \\
\hline Powdery mildew (Blumeria graminis) - \% infested culms of winter wheat & & 35.0 & 31.8 & 22.5 \\
\hline Septoria leaf spot (Phaeosphaeria nodorum) - \% infested ears of winter ears & & 19.1 & 17.5 & 11.6 \\
\hline Stem-mining weevil (Ceutorhynchus napi) - \% damaged plants in winter rape & & 14.1 & 13.7 & 5.0 \\
\hline Cabbage stem-weevil (Ceutorhynchus quadridens) - \% damaged plants in winter rape & & 29.0 & 25.2 & 9.0 \\
\hline Rape-seed weevil (Ceutorhynchus assimilis) - \% damaged siliques in winter rape & & 6.5 & 4.9 & 3.4 \\
\hline Brassica pod midge (Dasyneura brassicae) - \% damaged siliques in winter rape & & 5.0 & 4.6 & 3.7 \\
\hline Rape blossom beetle (Meligethes aeneus) - \% damaged flower buds in winter rape & & 16.8 & 13.8 & 9.8 \\
\hline Cereal aphid (Sitobion avenae) - \% infested culms in winter wheat & & 11.6 & 14.5 & 6.1 \\
\hline Bird cherry aphid (Rhopalosiphum padi) - \% infested culms in winter wheat & & 8.5 & 11.2 & 4.2 \\
\hline Fruit fly (Oscinella frit and Oscinella puzilla) - \% damaged corn plants & & 3.9 & 5.5 & 2.7 \\
\hline Colorado leaf beetle (Leptinotarsa decemlineata) - \% damaged potato plants & 24.9 & 24.5 & 31.3 & 16.7 \\
\hline
\end{tabular}

Bold text means the minimal and maximal values for each season.

ter the highest value of the coefficient of variation was recorded for the $3^{\text {rd }}$ cycle (1988-98), while the highest precipitation total was found in cycle IV (1999-2009), whereas it was lowest in cycle II (1977-87). In turn, for spring the highest value was found in cycle III (1988-98), in which precipitation total was the lowest, while the highest value was found in cycle I (1966-78). In summer the highest values of precipitation total and the coefficient of variation were recorded in the $2^{\text {nd }}$ cycle (1977-87), while on average the lowest precipitation total was found in the $1^{\text {st }}$ cycle (1966-76) (Table 2).

In summary, only in winter did precipitation reach the highest mean value in the $4^{\text {th }}$ cycle. In the other seasons in cycle IV precipitation was always greater in comparison to cycle III, but lower in comparison with cycles I or II (Table 2).

In the case of the coefficient of variation for air temperature the highest negative value was recorded in winter in the $1^{\text {st }}$ solar cycle, i.e. $-2055.2 \%$ (1966-76), while it was lowest in summer in the 1 st cycle (1966-76) and the $4^{\text {th }}$ cycle (1999-2009), in both cases amounting to $5.2 \%$.

In the case of autumn the highest value was found in the $4^{\text {th }}$ cycle, amounting to $42.6 \%(1998-2008)$, and at that time also mean temperature was highest $\left(4.6^{\circ} \mathrm{C}\right)$, whereas the lowest temperature was recorded in cycle I, being $3.9^{\circ} \mathrm{C}$ (1966-76) and in cycle III with $3.9^{\circ} \mathrm{C}(1988-99)$. For winter the coefficient of variation reached the highest value in cycle I (-2055.2\% in 1966-76), while temperature reached the highest value in cycle III $\left(1.5^{\circ} \mathrm{C}\right.$ in $\left.1988-99\right)$. In spring the highest coefficient of variation was found in the 1st cycle (10.6\% in 1966-76), while the highest temperature on average was observed, similarly as in autumn, in cycle IV $\left(13.5^{\circ} \mathrm{C}\right.$ in the years $\left.1999-2009\right)$. In summer the highest coefficient of variation was calculated for the $3^{\text {rd }}$ cycle
(7.3\% in 1988-98), whereas mean temperature, analogously to autumn and spring, was highest in the $4^{\text {th }}$ cycle $\left(17.4^{\circ} \mathrm{C}\right.$ in 1999-2009) (Table 3).

Summing up, on average temperature decreased in winter only in the $4^{\text {th }}$ cycle, although similarly as in the 3 rd cycle it was above zero (cycle III at $+1.5^{\circ} \mathrm{C}$, cycle IV at $+0.9^{\circ} \mathrm{C}$ ), while in autumn, spring, and summer in the $4^{\text {th }}$ cycle mean values of temperature were always highest in comparison to means in the other cycles (Table 3).

Generally speaking, the $1^{\text {st }}$ solar cycle was rather cold $\left(8.3^{\circ} \mathrm{C}\right)$ and of average humidity $(152.5 \mathrm{~mm})$, the $2^{\text {nd }}$ cycle was cold $\left(8.3^{\circ} \mathrm{C}\right)$ and humid $(188.1 \mathrm{~mm})$, the $3^{\text {rd }}$ cycle warmer $\left(8.6^{\circ} \mathrm{C}\right)$ and dry $(145.7 \mathrm{~mm})$, and the $4^{\text {th }}$ analyzed solar cycle was the warmest $\left(9.2^{\circ} \mathrm{C}\right)$ and of average humidity $(154.8 \mathrm{~mm})$.

\section{Pest Damages}

Among the agrophages (Table 4) in the last $\left(4^{\text {th }}\right)$ solar cycle damage potential increased only in the case of the European corn borer (Table 4).

Spring and summer are important periods in the development of the European corn borer. The pest pupates in May and females lay eggs toward the end of June. The further development is dependent, to a considerable degree, on air temperatures in summer, particularly temperatures in July and August, which considerably influence the final damage caused by this pest (Fig. 2). Different dependencies were analyzed in this study, but this one was definitely the most significant $(\mathrm{P}<0.001)$. An increase in temperature also results in the growing mean percentage of corn plants damaged by the European corn borer, observed in the successive solar cycles (Fig. 3). 
In the case of the bird cherry aphid and the cereal aphid found on winter wheat, fruit fly on corn, and the Colorado leaf beetle on potato, the greatest damages were observed in the $3^{\text {rd }}$ solar cycle (Table 4).

Taking into consideration their biology, wintering is an important period in the development of pests. The population size of the wintering population is determined by weather conditions found in winter. Air temperatures above zero and considerable amounts of precipitation result in the wintering stages being infected to a greater rate by, e.g., fungal diseases. In the $4^{\text {th }}$ cycle winter was characterized

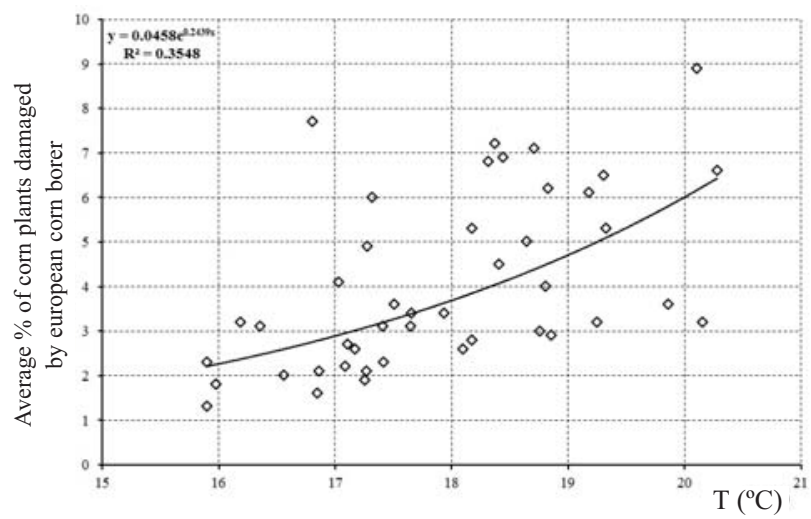

Fig. 2. National means for damages of the European corn borer depending on mean air temperatures in July and August for five cities in 1966-2009.

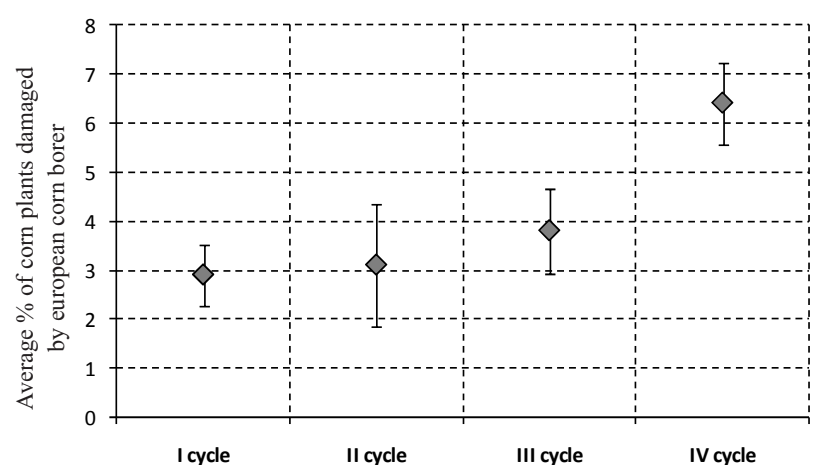

Fig. 3. National means for damages of the European corn borer in four solar cycles.

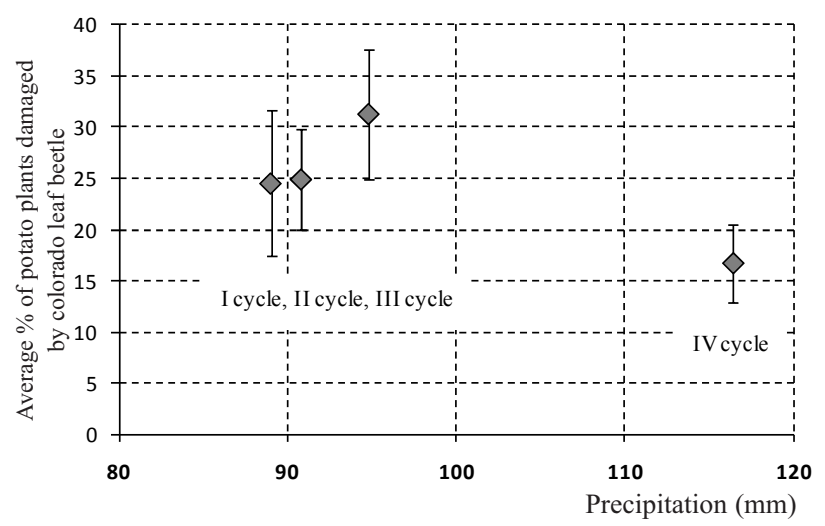

Fig. 4. Mean damages of the Colorado leaf beetle recorded in vegetation seasons depend on precipitation in the winter period (January, February, March) for each of the four solar cycles.

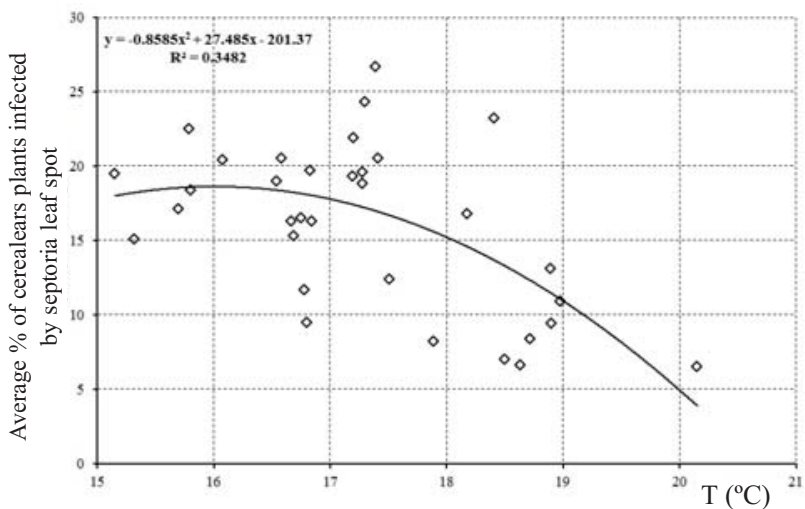

Fig. 5. Mean damages of septoria leaf spot depending on mean temperature in June and July in 1977-2009.

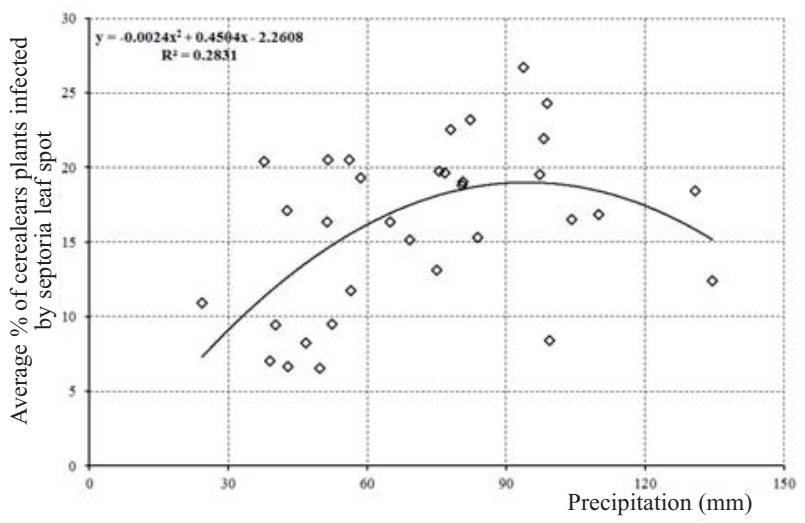

Fig. 6. Mean damages of septoria leaf spot depending on mean precipitation in June in 1977-2009.

both by greater precipitation than in the other cycles and average temperature of $0.9^{\circ} \mathrm{C}$, which did not promote pest overwintering, particularly in the case of the Colorado leaf beetle (Fig. 4).

The size of the Colorado leaf beetle wintering population and thus also its damages in the vegetation season decreased, which was promoted by precipitation in winter, particularly higher than in the other cycles. At precipitation ranging from $89 \mathrm{~mm}$ in the $2^{\text {nd }}$ cycle to $94.8 \mathrm{~mm}$ in the $3^{\text {rd }}$ cycle the percentage of plants damaged by the Colorado leaf beetle fell within a narrow range of 24.9-31.3. A considerable reduction of damages (to $16.7 \%$ ) was observed when the mean precipitation level increased in the $4^{\text {th }}$ cycle to $116.4 \mathrm{~mm}$ (Fig. 4).

Another group of agrophages comprised those for which greatest intensity of damages were observed in the $2^{\text {nd }}$ analyzed solar cycle, and next damages were gradually reduced in the successive solar cycles (Table 4). In the case of fungal diseases their lower intensity was a consequence of higher air temperatures and lower precipitation at the turn of spring and summer. For example, infestation rate with septoria leaf spot showed a significant dependence on mean temperature in June and July (Fig. 5) $(\mathrm{P}=0.021)$ as well as precipitation in June (Fig. 6) ( $\mathrm{P}=0.033)$.

We need to stress the fact that such a relationship was shown, although the available data comprised only mean 


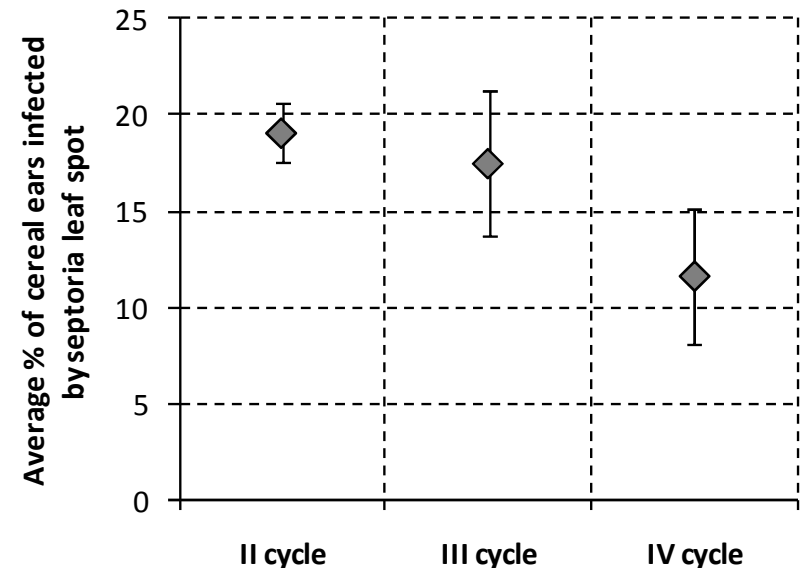

Fig. 7. Mean damages of septoria leaf spot with confidence intervals $(95 \%)$ for selected cities in three solar cycles.

ear infestation rates for the entire territory of Poland, while data on mean temperatures and precipitation were recorded in five cities. However, it needs to be stressed here that the locations were selected to represent different microclimates of Poland and it may be assumed that the obtained mean values were close to means for the entire country. It was shown that mean temperatures of June and July exceeding $17.5-18.0^{\circ} \mathrm{C}$ clearly do not promote the development of this disease. Similarly, it is not promoted by low precipitation levels in June, as in both discussed cases the percentage of infested ears in winter wheat was below $15 \%$. Moreover, in view of mean percentages of ears infected by septoria leaf spot in individual solar cycles (available data concerned only 3 cycles) it may be observed that the lower the damage potential, the higher the temperatures (Fig. 7).

In spring precipitation in the $4^{\text {th }}$ cycle in terms of its mean value $(164.6 \mathrm{~mm})$ was similar to that in the $3^{\text {rd }}$ cycle $(162.3 \mathrm{~mm})$, while air temperature in the $4^{\text {th }}$ cycle increased on average by as much as $1^{\circ} \mathrm{C}$, which did not promote the development of this disease. Good conditions for development of e.g. septaria leaf spot were found in spring in the $2^{\text {nd }}$ cycle (Tables 2 and 3 ).

For pests of rape (e.g. as the Colorado leaf beetle), winter months are important in their development. Wet winters contribute to a limitation of the size in the overwintering population (cycles IV and III - Table 2), similar to high air temperatures in winter (cycles III and IV - Table 3). These are the conditions at which increased activity is observed for natural enemies attacking wintering pest stages, which results in the reduction of their population sizes.

\section{Conclusions}

1. The highest coefficient of variation for precipitation was recorded in autumn in the 1st solar cycle (1965-75), when precipitation reached the highest level - the successive cycles were characterized by lower values and fluctuations in precipitation.

2. The highest coefficient of variation for air temperature was recorded for winter in the 1st solar cycle (in 196676).
3 . In the $4^{\text {th }}$ cycle only in winter did temperatures on average decrease, but they were still above zero (from $1.5^{\circ} \mathrm{C}$ to $0.9^{\circ} \mathrm{C}$ ), while in the other seasons they were higher than in cycles I, II, and III.

4. An increase in precipitation in winter months and higher values of mean air temperature in the $3^{\text {rd }}$ and $4^{\text {th }}$ cycles produced weather conditions contributing to a reduction of the population of wintering pest stages.

5. Stable precipitation and high temperatures in spring promoted the development of the European corn borer, while they did not promote the development of fungal diseases, e.g. septoria leaf spot.

\section{References}

1. ALCAMO J., MORENO J.M., NOVAK B., BINDI M., COROBOV R., DEVOY R.J.N., GIANNAKOPOULOS C., MARTIN E., OLESEN J.E., SHVIDENKO A. Europe. Climate Change 2007: Impacts, Adaptation and Vulnerability. Contribution of Working Group II to the Fourth Assessment Report of the Intergovernmental Panel on Climate Change, M.L. Parry, O.F. Canziani, J.P. Palutikof, P.J. van der Linden and C.E. Hanson, Eds.,Cambridge University Press, Cambridge, UK, pp. 541580, 2007.

2. CHRISTENSEN J.H., HEWITSON B., BUSUIOC A., CHEN A., GAO X., HELD I., JONES R., KOLLI R.K., KWON W.-T., LAPRISE R., MAGAÑA RUEDA V., MEARNS L., MENÉNDEZ C.G., RÄISÄNEN J., RINKE A., SARR A., WHETTON P. Regional Climate Projections. In: Climate Change. The Physical Science Basis. Contribution of Working Group I to the Fourth Assessment Report of the Intergovernmental Panel on Climate Change [SOLOMON, S., D. QIN, M. MANNING, Z. CHEN, M. MARQUIS, K.B. AVERYT, M. TIGNOR AND H.L. MILLER (eds.)]. Cambridge University Press, Cambridge, United Kingdom and New York, NY, USA, 2007.

3. SERBA T., LEŚNY J., JUSZCZAK R., OLEJNIK J. The effect of climate change on agriculture in Europe, the ADAGIO project - the first stage of realisation. Acta Agrophysica 13, (2), 487, 2009 [In Polish].

4. SADOWSKI M., WILKIN J., KOŁOMYJSKA I., KARACZUN Z., WITESKA K (Eds.). Agriculture and rural areas in view of climate change. FDPA, Warszawa, 114, 2008 [In Polish].

5. LEŚNY J. (Ed.). Climate change and agriculture in Poland impacts, mitigation and adaptation measures. Acta Agrophysica, Rozprawy i Monografie 1, 151, 2009.

6. WALCZAK F., TRATWAL A. Climate change as a factor influencing the economic importance of agrophages of agricultural crops. Prog. in Plant Protection/Post. Ochr. Roślin 48, (3), 808, 2008 [In Polish].

7. RYSZKOWSKI L., KĘDZIORA A. Agriculture and the greenhouse effect. Kosmos 42, 123, 1993 [In Polish].

8. LIPA J. J. World climate change - consequences for agriculture and plant protection. Prog. in Plant Protection/ Post. Ochr. Roślin 37, (1), 27, 1997 [In Polish].

9. http://www.ipcc.ch/report/ar5/wg2/

10. BOULLETINS OF THE STATE HYDROLOGICAL AND METEOROLOGICAL SERVICE. Instytut Meteorologii i Gospodarki Wodnej. Warszawa, 1965-2009 [In Polish]. 
11. KOZAK M., BOCIANOWSKI J., RYBIŃSKI W. Note on the use of coefficient of variation for data from agricultural factorial experiments. Bulgarian Journal of Agricultural Science 19, (4), 644, 2013.

12. HOYT D.V., SCHATTEN K.H. The Role of the Sun in the Climate Change. Oxford University Press, New York, 1997.

13. KERR R.A. A variable sun paces millennial climate. Science 294, 1431, 2001.

14. DOUGLASS D.H., CLADER, B.D. Climate sensitivity of the Earth to solar irradiance. Geophysical Research Letters 29, doi:10.1029/2002GL015345, 2002.
15. KIRKBY J. Cosmic rays and climate. Surveys in Geophysics 28, 333, 2007.

16. SCAFETTA N., WEST B.J. Is climate sensitive to solar variability? Physics Today 3, 50, 2008.

17. MEEHL G.A., ARBLASTER J.M., MATTHES K., SASSI F., VAN LOON H. Amplifying the Pacific climate system response to a small 11-year solar cycle forcing. Science 325, $1114,2009$.

18. SCAFETTA N. Empirical analysis of the solar contribution to global mean air surface temperature change. Journal of Atmospheric and Solar-Terrestrial Physics 71, 1916, (doi:10.1016/j.jastp.2009.07.007), 2009. 